\title{
Social, Psychological and Economic Impacts of Financial Assistance Provision For Poor Students in Primary School
}

\author{
Sudiyono \\ Department of Educational Management \\ Universitas Negeri Yogyakarta \\ Indonesia \\ sudiyono@uny.ac.id
}

\begin{abstract}
This research is aimed at describing the social, psychological and economic impacts of the provision of financial assistance for poor students or well-known as Bantuan Siswa Miskin (BSM). The research was done by using interview, observation, and documentation method. In this research, school principle, BSM fund managers, teachers, students as well as students' parents who receive BSM and community leaders were taken as the research subjects. In analyzing the data, Miles and Haberman model (Sugiyono, 2012) was used in the research. The model was including the data collection, reduction, the data presentation, and verification. The data analysis process was done interactively. The result shows that from the social perspective, students who receive BSM funds tended to make the interactions and also played with many friends, both in their school or in their residential environment. As well as for the students' parents, they had an opportunity to socialize with the society through PKK activity, regular social gathering, village association, mutual assistance, and others activities in celebrating some events on national and religious holidays. Psychologically, after students received BSM, they became happier, more diligent (in class, library, and home), discipline, having longer time for study, feeling healthy, having additional lesson outside the school, following the extracurricular activities, continuing education into the higher level, and having better achievements. Psychological impact for the teachers; they felt more comfortable and happy both in the learning process and in the interaction outside the class because students' condition, physically and psychologically, are cheerful, happier, cleaner, more diligent, and more confident. Psychologically, community leaders were also really happy because with BSM, all primary school age children could attend the school. It also could reduce the gap in the community so that needs, mutual cooperation attitude, and community tolerance can still be maintained. Economically, schools feel helped by BSM funds. Schools did not need to withdraw funds for students' personal needs. Parents were greatly helped by this BSM funds. The parents of BSM recipients were very excited and passionate in working to fulfil their family's needs; both for education needs, social needs, or even economic needs. According to them, because their children's personal needs for school have been fulfilled through BSM funds, so money which should be used for it could be allocated to another thing; business purposes. The parents of BSM recipients who work as construction labourers,
\end{abstract}

they bought building equipment for business capital. In addition, parents who have a home economy business would use the money to buy basic materials for business capital in order to increase their family income. Community leaders were also happy because with BSM, BSM recipients could try to increase their income through entrepreneurial activities.

Keywords-education finance, educational policy

\section{INTRODUCTION}

According to PISA's report [8] the achievement of Indonesian students in science and mathematics in PISA 2015 shows an increase compared to the year 2012. In this regard, socio economic factors still become one of the obstacles for students to achieve their maximum potential even tend to strengthen. It is explained that the difference of the average score between the group students with the lowest and the highest socioeconomic status reached 60 points. In general, the average score of rich families is likely to be higher than the average score of disadvantaged families.

Government through the Ministry of National Education has made various efforts in order to improve the quality of education. One of the efforts is government establish a compensation program for the poor, in the form of raskin program, community direct assistance (BLSM), basic infrastructure program and financial assistance for poor students (BSM). The BSM program is used for the purchase of books, materials, stationery, school bags, uniforms, as well as for the transport back and forth. The purposes of the BSM program are to remove the barriers of poor students to access education services, prevent the dropout rates and attract poor students to go back to school, help poor students to meet personal needs in learning activities, and support the completion of compulsory nine years basic education, secondary education and universal secondary education.

Sudiyono's research [6] related to the utilization of certification fund of high school and junior high school teachers in Sleman district shows that the certification fund is 
used for the education activities is $41.51 \%$, social $10.77 \%$, health $11,89 \%$, economy $27 \%$, politics $0,25 \%$, and others $9.08 \%$. So in this case the certification fund not only has a direct impact on education but also socioeconomic. It means that certification policies aimed at improving the professionalism of teachers are still low. However, if it is viewed from the welfare of teachers, it is increasing in terms of economic and social and health. Based on the above description then in this study should be seen the impact of providing BSM.

\section{LITERATURE REVIEW}

\section{A. Poverty}

[7] Poverty is a situation experienced by a person who is not able to organize his life until a level that is considered humane. Dimensions are political, social, cultural, psychological and economic and access to assets. Furthermore, the characteristics of the poor according to Tim Crescent (2003): politically have no access to decision-making processes concerning their lives; socially excluded from the main institution of existing societies; economically, the degradation of the quality of human resources including health, education, and skills affecting income; in culture and values point of view, caught up in the culture of low quality of human resources, such as low work ethic, short thinking and fatalism; based an environment point of view, the low ownership of physical assets including environmental assets, such as clean water and lighting.

\section{B. Bantuan Siswa Miskin or Financial Assistance for Poor Students}

According to Kemendikbud, (2013) the number of drop outs is mostly $(75.7 \%)$ due to economic reasons, both because it has no cost $(67 \%)$ and because the child has to work $(8.7 \%)$. In order to prevent a policy from having a negative impact on school enrolment rates, a Social Safety Net (JPS) policy is enacted and then continued with the Financial Assistance for Poor Students (BSM). BSM is government assistance in the form of cash provided directly to students coming from poor families (Kemendikbud, 2013).

BSM aims to remove the barriers of poor students to access education services, prevent dropout rates and attract poor students to go back to school, help poor students to meet personal needs in learning activities, and support the completion of compulsory nine years basic education, secondary education and universal secondary education.

The target of poor students assistance program is poor students who in the academic year 2013/2014 are still elementary students, junior high school, senior high school and vocational school and meet at least one of the criteria; students whose parents are the recipients of social protection cards (KPS); students receiving candidate card for poor students especially for elementary and junior high school, parents are enrolled as participants of the hope family program, students are in danger of dropping out of school due to cost difficulties, orphaned students, students come from victims of disasters, physical abnormalities, victims of layoffs, and the students from very poor households.

\section{The Policy Impact Model}

A new policy can be seen if the results have been evaluated. Evaluation is "the process of assigning value to some objective and then determining the degree of success in attaining this valued objective" [5]. [2][5] Evaluation is "the mean of determining the extent to which a program is yielding its objectives, using available methods to give evidence that is objective, systematic and comprehensive". While Marshall (1994) states that the evaluation is "a type of policy research devoted to assesing the consequences, intended and unintended, of a new policy program or of an extent to which stated goals and Objectives are being me and measurement of displacement and substitution effects ". Coleman (Dolbeare, ed. 1975) states that "for policy research, the ultimate product is not a" contribution to existing knowledge in the literature, but a social policy modified by the research result ". Ronald W Johnson (Dolbeare, 1975) states that policy research can also find expected and unexpected impacts including attitudes and behaviors as a series of impacts of those policies.

Thomas J. Cook and Frank P. Scioll, Jr., in Kenneth M. Dolbeare (1975) provide an explanation that policy impact analysis with the logic that policy is derived in a work program. Each program has a purpose (specific). In order to achieve that goal, it requires an activity. The extent to which the success of the activity is measured by its size or criteria of effectiveness, the policy impact is the result of policy effectiveness.

In this case, the impacts are divided into the expected primary and secondary impacts, as well as the unexpected primary and secondary impacts. In other words, every policy has intended impact and unintended impact. Solichin (1997) argues that the impact evaluation literature is used to indicate the relevance or significance of a project or program, it is only an impact if a project has resulted in certain result, whether desired or not.

According to Ensor Team, et al., for twelve years in Cambodia, health policy is focused on a policy to alleviate the costs of improving access specifically to vulnerable groups. This policy is in the form of health financing policies, including fair health funds, coupons and public health insurance and complemented by continuously different service incentives. The socioeconomic survey in Cambodia shows the impact of the policy: household expenditures increased five times from 2005 prices between 1997 and 2009 and as the proportion of income spent on health increased from $2 \%$ to almost $10 \%$, even for the richest can increase to $11 \%$ for total health consumption.

Tomoaki (2017) developed a link between public school spending and mobility in America. According to him, if public school spending is not distributed fairly then intergenerational mobility will be low. The model of public school funding uses two systems, namely a full funding program and a foundation program. He states that diverting a full funding program would improve intergenerational mobility but not very large. This is because the full funding by the state 
limits public school expenditures or expenditures that will hinder intergenerational mobility.

On the basis of the results of the theoretical studies and the results of the research described above, this study focuses on how the impact of providing BSM for students, parents and schools, as well as the community.

\section{RESEARCH METHOD}

This research was an exploratory research. This research was conducted to gather information related to the impact of BSM for students, parents, and school. This research took place at SD Negeri Sukasari, Ngaglik, Sleman. Key informant in this research was a school principal, while the informants in this research were teachers, students, and parents who accept BSM in SD Negeri Sukasari, Ngaglik, Sleman. Data collection technique was done by using interview and documentation method. The instrument of this study was an interview guide. Qualitative analysis technique Huberman model (1992) was used to analyse the data.

\section{FINDINGS AND DISCUSSION}

\section{A. Social Impact}

1. For students: BSM recipient students increasingly interact and play with many friends, both in school and in their neighbourhood.

2. For parents of BSM recipients, they have the opportunity to socialize with the community through PKK activities, social gathering, village associations, visiting sick neighbours and families, mourning, mutual cooperation, and various contest activities in the community for national or religious holidays.

\section{Social Impact for school}

The provision of BSM has an impact on increasing motivation so the institution diligently follows various exercises in extracurricular activities. Based on this activity, the school received a championship at the sub district level in the form of tilawatil Al-qur'an as well as a small doctor competition. The result of these contests has an impact to this school.

\section{B. Psychological Impact}

1. For students who receive BSM funds, they more often to interact and play with many friends, both in school and in the environment where they lived. Based on the observation, the students are also more passionate and discipline. They are active because they are more confident. Academic and nonacademic achievements are also increasing. They are comfortably socializing with friends who do not receive the funds. The researcher's observation during both in the class and in the field (while they are doing sport activity) learning processes shows that there is no difference between they who receive the funds and they who do not. They get along together. Indeed BSM recipient students initially somewhat lack of confidence, feeling shame, and feeling low self-esteem. However, when they got the funds, those feelings are decreasing and they become confident. Thus, these are the psychological impacts for the students who receive BSM funds.

2. For parents, the parents of BSM recipients explain that there is an increase in diligence, discipline and study time ( 1 hour to 1.5 hours) as well as 30 minutes of recitation activities. Learning achievement is also increasing. Their children also want to continue their education as high as possible.

3. For school in extra curriculum activities: students who receive $\mathrm{BSM}$ funds become motivated to follow various exercises in extracurricular activities. Based on this activity the school received a championship at the sub-district level in the form of: chess championships, tilawatil Qur'an, and a small doctor competition.

4. For teachers: Based on interviews with teachers, it finds that BSM recipient students no longer wear damaged shoes, one book for one lesson, bags that are also not damaged and clothes are not worn and ragged. Among the students who receive BSM funds, there is a student who gets the 1st rank even if he/she did not follow the additional course, especially if the student follows the course, it will be better. The students are also happy to interact with friends both in class and outside the classroom. The teachers stated that it is very comfortable and happy both inside and outside the classroom.

\section{Economic Impact}

1. The parents who do economic activities in the form of a grocery stall.

Parents are greatly helped by this BSM assistance. BSM recipient parents are very excited and passionate in the form of increasingly diligent work to meet the needs of their families both for short and long term, both for educational purposes and other purposes. According to the parents because the personal needs of their children's school has been fulfilled through BSM funds, then the funds that should be used to pay for their children's school needs are used for business purposes. The parents of BSM recipients who work as construction labourers, they buy building equipment for venture capital. Parents who have a home economy business purchase basic materials for business capital to increase family income.

2. Community leaders are also happy because with BSM, parents of BSM beneficiaries can seek to increase their income through entrepreneurial activities.

\section{For the society}

Disparities between people become reduced so it can reduce the social jealousy. People become more understand and appreciate of each other.

\section{Negative Impact}

Those eligible to receive BSM are students from poor families excluding civil servants, POLRI and TNI. In terms of facts, civil servants, POLRI and TNI whose incomes are lower than the general public, their child feels jealous why his friend got BSM funds, while they do not get it. 


\section{CONCLUSIONS AND SUGGESTIONS}

The conclusion that can be drawn is that the provision of BSM funds has social, psychological, and economic impacts. Social impact: schools become known, teachers feel comfortable and happy, students' interaction increases, parents can socialize with the community in various activities. Psychological impact: for students, they feel happy and motivated in various activities both intra and extra curriculum and to continue higher education, teachers become more comfortable and happy, parents become more motivated to work, the community is also happy because there is no schoolaged children who cannot go to school.

BSM increases with inflation rate and BSM is also given to civil servants, POLRI and TNI.

\section{REFERENCES}

[1] Dolbeare, M. Editor. (1975). PublicPolicy Evaluation, Volume II. London: Sage Publications.

[2] Jenkins, WJ, (1978). Policy Analysis: A Political dan Organizational Prespective, London

[3] Kementerian Pendidikan dan Kebudayaan, (2013). Panduan Bantuan Siswa Miskin (BSM), Jakarta
[4] Marshall, Gordon (ed).1994). The Concise Oxford Dictionary of Sociologi, Oxford, Oxford University

[5] Suchman, EA,(1967) Evaluative Research: Priciple and Practice in Public Service and Social Action Programs, NewYork, Sake

[6] Sudiyono. (2010). Dampak Sertifikasi pada guru SMP se kapupaten Sleman, Hasil Penelitian, FIP UNY.

[7] Tim Crescent, (2003). Menuju Masyarakat Mandiri, Pengembangan Model Sistem Keterjaminan Sosial, Jakarta, PT Gramedia Pustaka Utama

[8] Elin Driana, (2017). Pemerataan Pendidikan Bermutu, Kompas, Selasa 10 Januari 2017,hal6

[9] Tim Ensor, et.all 2017. Impact of Health Financing Policies in Cambodia: A 20 year Experience, Journal Homepage:www.elsevier.com/locate/socscimed.

[10] Tomoaki Kotera, Ananth Seshadri, 2017. Educational Policy and Integenerational Mobility, Review of Economic Dynamics, WWW.elsevier.com/locate/red

[11] Sugiyono, (2012). Metode Penelitian Kombinasi (Mixed Methodes), Bandung, Alfabeta

[12] Solichin, Abdul Wahab (1997). Evaluasi Kebijakan: Konsep Tipologi Penelitian, dan Strategi Pemecahannya, Malang, FIA UIBRAW dan Penerbit IKIP MALANG 